\title{
DESPRE CONTEXTUL ACTUAL ÎN CERCETAREA METAFOREI. METAFORĂ ȘI AFECTIVITATE
}

\author{
ELENa FAUR \\ Academia Română, Institutul de Lingvistică și Istorie Literară \\ „Sextil Puşcariu”, Cluj-Napoca, România
}

Rezumat. În ultimii ani, tot mai mulți cercetători consideră că cercetarea metaforei ar putea profita de pe urma unei integrări a ideilor dezvoltate de orientări distincte sau chiar divergente. In lucrarea de față voi urmări un țel similar și voi propune o integrare a unor tradiții distincte de cercetare. Este vorba, pe de o parte, de o tradiție care iși are punctul de origine în lingvistica integrală a lui Eugeniu Coșeriu și, pe de altă parte, de o altă tradiție de cercetare care pornește de la Teoria Metaforei Conceptuale și orientările asociate acesteia. În prima parte a lucrării voi expune o imagine de ansamblu a perspectivei coșeriene asupra metaforei și a concepției sale cognitive, intemeiată pe tradițiile majore europene din filosofia limbajului. In a doua parte voi schița peisajul curent al cercetării metaforei din metaforologia actuală, încercând să identific achizițiile științifice importante de care ar putea profita cadrul integralist. La final voi argumenta că conceptul de „emoție” dezvoltat de M. Johnson $(2017,2018)$ și inspirat din ideile provenite din operele Lui W. James, J. Dewey și A. Damasio - și cel de ,inter-afectivitate”, elaborat de Fuchs şi Koch (2014), au cel mai mare potențial de a fi integrate în teoria integralistă a metaforei.

Cuvinte-cheie: metaforă, afectivitate, emoție, Teoria Metaforei Conceptuale, lingvistica cognitivă, lingvistica integrală.

Abstract. Over the past years, there is a growing agreement between scholars within Cognitive Linguistics that metaphor research cannot but profit from integrating ideas developed within separated and eventually diverging strands of research. I consider a similar goal in the present article and propose an integration of more widely divergent traditions of research. One is originating from Coseriu's Integral Linguistics and the other from Conceptual Metaphor Theory and associated trends. The paper starts from an outline of Coseriu's view on metaphor and of his distinctive cognitive perspective, grounded in the major European traditions in the philosophy of language. Searching for significative achievements which the integralist framework may benefit from, I subsequently survey the current landscape of metaphor research in present-day metaphorology. In the end, I argue that Johnson's $(2017,2018)$ concept of ,emotion" - inspired by ideas emerging from the works of W. James, J. Dewey and A. Damasio - and the concept of ,interaffectivity", elaborated by Fuchs and Koch (2014), are the ones with the strongest potential to be integrated within the integralist theory of metaphor.

Keywords: metaphor, emotion, affectivity, Conceptual Metaphor Theory, Cognitive Linguistics, Integral Linguistics. 


\section{Introducere}

În ultimii ani, cercetătorii metaforei au căzut de acord asupra faptului că studiul metaforei ar putea profita de pe urma unei integrări a ideilor dezvoltate de orientări distincte sau, la prima vedere, chiar divergente. Astfel, în introducerea la volumul ce reunește lucrările prezentate la cea de-a 10-a conferință a Asociației pentru Cercetarea și Aplicarea Metaforei (Association for Researching and Applying Metaphor), care a avut loc în 24 iunie 2014, în Cagliari, Italia, B. Hampe (2017, p. 4), editoarea volumului, afirmă: ,este momentul ca teoria metaforei să integreze intuițiile majore" dezvoltate de „linii de cercetare în mare măsură încă separate, dar, în cele din urmă, complementare"1. Desigur, B. Hampe se referea, în acest context, la liniile de cercetare derivate din teoria lakoviană a metaforei conceptuale (TMC) și la orientările asociate acesteia. Acest câmp al cercetării, de altfel extrem de înfloritor, cunoaște, în ultima perioadă, o polarizare extrem de puternică, care se reflectă în așa-zisele „războaie ale metaforei” (Gibbs, 2017a). Care ar fi însă șansele de reușită a integrării unor tradiții divergente de cercetare? Care ar fi progresele semnificative în cercetarea curentă a metaforei de care teoria integralistă ar putea profita? Cum pot fi acestea acomodate cu cadrul integralist în studiul metaforei? Și ce ar putea învăța, în schimb, alte orientări din teoria integralistă a metaforei? Prezentul articol ridică aceste întrebări și propune să aducă împreună tradiţia de cercetare care își are originea în lingvistica integrală coșeriană, pe de o parte, și, pe de altă parte, în TMC și direcțiile asociate sau inspirate de aceasta.

În Secțiunea 2 vom prezenta, pe scurt, perspectiva teoretică distinctă în care Coșeriu încadrează teoria sa a metaforei din singurul studiu dedicat extensiv acestui fenomen, La creación metafórica en el lenguaje, din 1956. În Secțiunea 3 vom încerca să oferim o imagine de ansamblu asupra celor mai importante câștiguri din câmpul cercetării actuale, efectuate din perspectiva TMC lakoviene și a orientărilor asociate acesteia și vom sublinia potențialul câtorva dintre aceste achiziții de a contribui la progresul studiului metaforei din perspectivă integralistă. În acest sens, în ultima sub-secțiune vom argumenta că conceptul de „emoție”, dezvoltat de M. Johnson $(2017,2018)$ și cel de ,inter-afectivitate”, elaborat de Fuchs și Koch (2014), au cel mai mare potenţial de a fi integrate, în momentul actual, în teoria integralistă a metaforei. Concluziile din Secțiunea 4 pledează pentru necesitatea continuării dialogului între teoria integralistă a metaforei, dezvoltată pe baza lingvisticii integrale coșeriene, și alte tradiții de cercetare.

1 ,it is high time for metaphor theory to integrate major insights” from ,yet largely separate, but ultimately complementary strands of inquiry". Menționez că toate traducerile în limba română ale fragmentelor citate în acest text îmi aparţin. 


\section{Bazele teoriei integraliste a metaforei}

Asumpția de la care vom porni este aceea că lingvistica integrală coșeriană este convergentă, în anumite aspecte, cu poziția centrală atribuită procesului metaforic în cadrul mișcării orientate „cognitiv” din cercetarea actuală a metaforei. În același timp, poziția coșeriană - expusă în studiul său La creación metafórica en el lenguaje, deja în 1956 - se prezintă ca fiind bazată pe o perspectivă teoretică distinctă, întemeiată pe tradiția europeană majoră din filosofia limbajului și a culturii (Aristotel, Vico, Hegel, Humboldt). Coșeriu ia ca punct de pornire în încadrarea teoriei sale metaforice noțiunea lui Ernst Cassirer a activității culturale așa cum este manifestată ea prin „formele simbolice” ale limbajului, artei, mitului și științei. Totuși, Coșeriu subliniază faptul că ,adjectivul simbolic [...] nu ne spune ce tip de activitate este limbajul, ci numai îl caracterizează, indică natura elementelor sale și momentul în care acesta se articulează” (Coșeriu, 2001 [1956], p 14). Astfel, „simbolicul” stă pentru „,o etapă secundară în delimitarea limbajului ca activitate”, care implică, „,̂n mod necesar o etapă anterioară” (ibid.), i. e. momentul recunoașterii că „limbajul este modalitatea specifică a omului de a cunoaște realitatea, realitatea $s a$ " (ibid.; subliniere în original). Bazat pe conceptul acesta „mai amplu” al cognitivului, limbajul este apoi definit ca fiind ,în mod esențial activitate cognitivă: activitate de cunoaștere care se realizează prin simboluri (sau semne simbolice)" (ibid.).

Așa cum au sugerat câțiva autori (Sanchez de Zavala, 1982, p. 23-24; Vilarnovo Caamaño, 1993, p. 158-159 ș. a.), Coșeriu face aici un pas important pentru introducerea unei perspective „,cognitive” asupra limbajului, care este demnă de menționat deoarece lingvistica cognitivă s-a constituit ea însăși ca o paradigmă importantă de cercetare în a doua jumătate a secolului al XX-lea. O relevanță semnificativă în acest studiu are rolul atribuit de Coșeriu creației metaforice în limbaj în termenii unei ,,activități libere a imaginației” (Coșeriu, 2001 [1956], p. 29). Pentru Coșeriu, această activitate este mult mai mult decât ceea ce se înțelege prin ocurențele ,infinite”, dar superficiale, ale unor expresii glumețe, comune în uzul lingvistic obișnuit. El are în vedere metafora la „un nivel mai adânc", unde aceasta este motivată de funcția ei primară de „distincție, clasificare și denumire inițială a ceea ce este cunoscut, a ceea ce se prezintă în realitate în intuiția omului - creator al lumii sale specifice și al limbajului său (activitate care se situează ca punte mediatoare între conștiință și lume)" (Coșeriu, 2001 [1956], p. 30).

Important, din punct de vedere teoretic, este faptul că, în opoziție cu E. Cassirer, Coșeriu situează metafora în cadrul funcției semnificative a limbajului. Această funcție semnificativă este, la rândul ei, situată, explicit, în interiorul dimensiunii creativ-cognitive a tuturor activităților „culturale” (sau „intelectuale”) ale ființei umane. În studiile mai târzii, Coșeriu dezvoltă acest punct de vedere asupra limbajului, atât în ceea ce privește implicațiile teoretice, cât și rădăcinile lui în istoria științelor 
limbajului (cf. mai ales Coșeriu 1995, 2000 [1990], 2007 [1998], 2015, I, p. 312-313).

$\mathrm{Nu}$ voi realiza, în continuare, o „exegeză” a unei părți a lingvisticii integrale coșeriene, respectiv a abordării lui a metaforei. Scopul prezentei lucrări este acela de contribui la dezvoltarea teoriei integraliste a metaforei, urmând linia de cercetare din cadrul programului de „Studii integraliste” de la Universitatea Babeș-Bolyai din Cluj-Napoca, al cărui obiectiv principal este, așa cum subliniază Bojoga, Boc și Vîlcu (2013, p. 6), de a dezvolta, ,într-o manieră creativă și originală”, ,perspectiva deschisă de Coșeriu în domeniul științelor limbajului și în disciplinele adiacente"².

\section{Relația dintre studiile integraliste și orientările alternative din cercetarea actuală a metaforei}

Cum se raportează studiile integraliste ale limbajului la orientările alternative din cercetarea actuală a metaforei? Care sunt progresele semnificative în cercetarea curentă a metaforei de care teoria integralistă a metaforei ar putea profita? Cum pot fi acestea acomodate cu cadrul integralist în studiul metaforei? Și ce pot învăța, în schimb, alte orientări din teoria integralistă a metaforei? În continuare vom încerca să răspundem la aceste întrebări.

3.1. Perspectiva neurală asupra metaforei. Cercetarea curentă a metaforei pare a fi foarte diversificată. O primă linie majoră de cercetare, reprezentată de G. Lakoff și J. Grady, asumă „o teorie neurală a metaforei". Această teorie a fost criticată din multe puncte de vedere. O obiecție puternică la adresa explicației neurale a stabilității metaforice a fost ridicată recent de Zlatev, Jacobsson și Paju (2021, p. 45-46). Autorii întreabă: „,U]nde este localizat acest 'sistem conceptual' și dacă 'în creier', dat fiind că Teoria Metaforei Conceptuale a tins să devină o 'teorie neurală a metaforei' (Lakoff, 2009), al cui creier și cum pot ele rămâne acolo pentru o perioadă indefinită de timp?"3 Alte argumente importante împotriva „fundamentării neurale” a teoriei metaforei au fost prezentate dintr-un punct de vedere integralist în câteva studii (Borcilă, 2003; v. și Faur, 2013a, 2013b). Principala eroare a teoriei neurale constă, din această perspectivă, în incapacitatea de a explica natura creativ-semantică a metaforei. Dacă principiul explicativ al creativității metaforice este căutat și găsit dincolo și înainte de activitatea creativ-cognitivă însăși, în care metafora se presupune că ar emerge, atunci metafora încetează a mai fi un fenomen creativ. În schimb, devine un fenomen care este condiționat

${ }^{2}$, , [une tentative de] valorisation créative et originale de la perspective ouverte par Coseriu dans le domaine des sciences du langage, ainsi que dans les disciplines adjacentes".

3 ,[W] [Were is this 'conceptual system' located, and if in 'the brain', given that CMT has been aiming to become a 'neural theory of metaphor' (Lakoff 2009): whose brain, and how can they remain there indefinitely?" 
de ceva de o altă natură. Poziția asumată de Grady (Grady și Ascoli, 2017, p. 29-30) merge mai departe și ajunge la postularea caracterului înnăscut al sistemului nostru conceptual: „conceptele primare sursă și țintă sunt bazate pe experiențe care sunt, într-un sens semnificativ, parte a repertoriului cognitiv înnăscut al omului" ". In acest fel se proiectează o constrângere dublă asupra creativității metaforice. Este evident că interpretările cauzale ale metaforei, propuse de Lakoff și Grady, nu pot fi în nici un fel acomodate cu orientarea integralistă în cercetarea metaforei. Motivația principală a acestui dezacord constă în faptul că aceasta din urmă se bazează pe un principiu explicativ al creativității semantice cu totul diferit. Acest principiu își are punctul de pornire în conceptul lui Coșeriu de energeia, un concept pe care acesta îl situează la baza tuturor activităților culturale umane.

\subsection{Perspectiva socio-discursivă și perspectiva orientată asupra} aspectului cognitiv. Există o dezbatere vie în momentul actual între cercetători care abordează metafora din perspective opuse: fie dintr-o ,perspectivă socio-discursivă”, ,i.e. metafora ca aparținând în mod primar limbajului și interacțiunii sociale", fie dintr-o perspectivă axată asupra dimensiunii cognitive, ,i.e. metafora ca aparținând în mod primar (sau avându-și punctul de origine în) sistemul conceptual al unui individual"' (Jensen, 2017, p. 258). Această polarizare între orientările care pun accent asupra primatului dimensiunii cognitive și cele care se focalizează asupra aspectului discursiv în cercetarea metaforei poate fi abordată și prin trasarea unor dihotomii mai fine și punctuale: (1) perspective universaliste vs orientate specific-cultural; (2) perspective orientate asupra aspectului cognitiv vs perspective orientate asupra dimensiunii comunicative; (3) orientări care vizează stabilitatea metaforei vs orientări care urmăresc dimensiunea dinamic-procesuală a metaforei ${ }^{7}$. Totuși, există și încercări de a integra, în modele comprehensive, intuițiile prezente în variate perspective, care, la o primă vedere, par a fi conflictuale. Unul dintre cele mai comprehensive modele, care oferă și o soluție teoretică promițătoare asupra modului în care aceste perspective contradictorii pot fi „,negociate” și integrate unele cu altele este cel care poartă numele de „Modelul Motivării și Sedimentării”. Acest model a fost dezvoltat într-un cadru semiotic-cognitiv (v. Zlatev, Jacobsson și Paju, 2021; cf. și Devylder și Zlatev, 2020; Stampoulidis, Bolognesi și Zlatev, 2019). În continuare voi confrunta o serie de idei de referință din cercetarea actuală a metaforei cu intuițiile similare din teoria integralistă.

4 ,primary source and target concepts are grounded in experiences that are, in some meaningful sense, part of humans' innate cognitive repertoire".

5 ,i.e. metaphor as primary belonging to language or social interaction"

6 ,i.e. metaphor as primary belonging to (or originating from), the individual's conceptual system"

${ }^{7}$ Pentru o prezentare a acestor sub-diviziuni, a se vedea Zlatev, Jacobsson și Paju (2021). 
O discuție interesantă privind problema relației direcționale dintre,,sursă" și ,țintă” este ridicată de Shen și Porat (2017), dintr-o perspectivă orientată asupra aspectului cognitiv al metaforei. Autorii pornesc de la câteva rezultate ale cercetării din psiholingvistică ce ridică întrebări asupra unidirectionalitătii cartărilor metaforice în TMC. Dacă metaforele conceptuale sunt bazate pe co-activarea unor domenii eterogene ca rezultat al conflaţiei lor repetate în experiențele primare ale infantului (de exemplu, între sentimentul de afecțiune și căldura fizică a corpului îngrijitorului) și dacă metaforele conceptuale se presupune că emerg prin proiecția sau cartarea de la un domeniu la altul, de la sursă la țintă, atunci, următoarele ,discrepanțe” trebuie să fie explicate: Cum poate fi menținută bidirecționalitatea implicată în procesul neural al coactivării domeniilor, dacă procesul de proiecție sau cartare se presupune că e unidirecțional? Care este relația dintre ambele procese, iar dacă există o trecere de la un proces la altul, ce stă la baza acestei schimbări? Şi, chiar mai important, de ce metaforele lingvistice par să demonstreze mai degrabă unidirecționalitate, decât bidirecționalitate, în ceea ce privește procesul de proiecție? ${ }^{8}$ Shen și Porat (2017) argumentează în favoarea unei soluții bazate pe distincția dintre două ,tipuri” - sau, mai degrabă două „faze” ale procesării metaforice: (1) conceptuală și bidirecțională și (2) lingvistică și unidirecțională. Prima fază se referă la „o fază inițială a formării și înțelegerii metaforei” (Shen și Porat, 2017, p. 68), în care domeniile sunt, ,simplu 'asociate' și care nu implică o atribuire a [rolului de] 'sursă' sau 'țintă"”' (Shen și Porat, 2017, p. 67). Cea de-a doua se referă la o metaforă lingvistică în adevăratul sens al cuvântului, în care aspecte ale domeniului-sursă sunt proiectate sau cartate la aspecte ale domeniului-țintă și unde procesul unidirecțional este cerut de ,atribuirea funcției gramaticale” și, astfel, de ,alocarea” unui rol fie de „sursă”, fie de „tintă” termenilor metaforici (Shen și Porat, 2017, p. 71).

Chiar dacă nu împărtășesc soluția propusă de Shen și Porat (2017), insistența autorilor asupra nevoii de a discuta aspectul unidirecționalitătiii, în corelație cu noțiunile de „sursă” și ,,tintă”, precum și sugestia lor potrivit căreia în primul tip de metaforă conexiunea între cele două domenii ar trebui înţeleasă ca „simplă asociație”, fără nici o ,atribuire a rolului de sursă sau țintă", reprezintă un binevenit punct de discuție. Același aspect a fost discutat critic din perspectiva poeticii cognitive de Stockwell (1999). Potrivit acestuia, ceea ce se întâmplă când conceptualizăm noi experiențe prin metaforă nu este un fapt de proiecție de la o sursă la o țintă, ci un proces care presupune o ,influență reciprocă” a celor doi termeni implicați în procesul metaforic.

${ }^{8}$ Shen și Porat (2017) analizează exemple precum $O$ ancoră este un prieten și (deja faimosul) Acest măcelar este un chirurg și demonstrează că schimbarea rolurilor de sursă și țintă duce la o interpretare total diferită a metaforelor, chiar dacă un proces bidirecțional al proiecției rămâne totuşi posibil în astfel de cazuri.

9 ,initial phase of metaphor formation and comprehension”, where the domains are „simply 'associated' and which involves no attribution of 'target' and 'source”". 
Folosind exemple variate, el argumentează că termenii „sursă” și „,tintă” sunt nepotriviți și ar trebui abandonați. Un punct de vedere similar avansează și Sonesson (2015), în domeniul semioticii vizuale, cu privire la conceptele paralele de „topic” sau „tenor” și ,vehicol” care circulă în retorică. Sonesson argumentează că, în metafora din domeniul vizualului, ,este deseori imposibil să decizi care termen este "vehicolul' și care este 'tenorul""10 și că „direcția comparației” este clarificată doar de „,contextul mai larg” (Sonesson, 2015, p. 99-100).

Shen și Porat, la fel ca și Stockwell și Sonesson, ajung la concluzii similare, chiar dacă pornesc de pe poziții distincte și avansează argumente foarte diferite. Ei propun abandonarea relaţiei direcționale dintre 'sursă' și 'țintă' (sau 'vehicol' și 'tenor') și subliniază că legătura dintre domenii nu este în mod necesar asimetrică. Perspectiva integralistă este apropiată de poziția lui Stockwell și de cea a lui Sonesson. În linie cu asumpțiile humboldtiene care stau la baza teoriei integraliste a metaforei, transferul între domenii nu are loc între două entități lexicale pasive, în care primul (sursa) ar avea doar rolul de a sigura structura celui de-al doilea domeniu (ținta). În schimb, conținuturile ambilor termeni fuzionează și contribuie, în proporții diferite și cu conținut semantic specific, la procesul metaforic. Cu alte cuvinte, amândoi itemii lexicali contribuie activ la emergența entității metaforice noi, creată pe baza unei „viziuni” a aspectului unitar al celor două conținuturi diferite. În concordanță cu evaluarea TMC din perspectivă integralistă, Stockwell (1999, p. 140) subliniază faptul că conceptele de 'sursă' și 'țintă' au subminat încă de la început ,percepția metaforei ca fiind creativă”, ,,condamnându-ne să vedem lucrurile în același fel în care le-am văzut dintotdeauna"11. Evaluarea lui Sonesson $(2015,2019)$ demonstrează, la rândul ei, că ceea ce Lakoff și Johnson numesc metaforă ar corespunde, de fapt, diagramelor în sens peircean. Similar argumentului lui Stockwell, Sonesson subliniază că metaforele din TMC se axează mai degrabă asupra ,echivalențelor statice” care sunt taken for granted în lumea vieții, și nu similarităților care sunt „,nou create” prin metaforă.

Teoria integralistă a metaforei poate acomoda totuși conceptele 'sursă' și 'țintă' dintr-o perspectivă funcțională. La prima vedere, soluția integralistă pare să fie, într-o anumită măsură, convergentă cu perspectiva lui Shen și Porat (2017), mai ales în ceea ce privește considerarea relației asimetrice dintre termeni în metafora lingvistică dintr-un punct de vedere funcțional. Diferența constă în faptul că, pe când Shen și Porat restrâng perspectiva funcțională la rolul de sursă și țintă dintr-o propoziție sau frază (situând, deci, întreaga problematică a metaforei în limbaj la nivelul istoric în matricea coșeriană), în teoria integralistă a metaforei această perspectivă este înțeleasă în raport

\footnotetext{
10 ,it is often impossible to decide which term is the "vehicle' and which 'the tenor"”

11 „the perception of metaphor as creative”, ,condemning us to see things only in the way that we have always seen them".
} 
cu natura cognitivă a metaforei și deci cu dimensiunea referențială a vorbirii ('designația'): metafora este creație de conținuturi cognitive în vorbire (în plan universal) cu finalitatea de ,clasificare a realității” (Coseriu, 2001 [1956], p. 14). Astfel, dacă luăm în considerare perspectiva integralistă a „creației metaforice în limbaj" și cele mai noi dezvoltări din paradigma cognitivă dintr-o perspectivă funcțională, presupusa „diviziune a muncii” (Shen și Porat, 2017, p. 71) între două 'tipuri' foarte diferite de procese metaforice, și probabil ireconciliabile - conceptual și lingvistic - nu mai pare a fi necesară.

În contrast cu orientările care accentuează asupra primatului dimensiunii cognitive, cercetătorii care adoptă perspectiva socio-discursivă au făcut un efort consistent în direcția revigorării interesului pentru dimensiunea socioculturală și comunicativă a metaforei. Cercetători precum Leezenberg (2013), Caballero și Ibarretxe-Antuñano (2013), Forceville (2017), Winter și Matlock (2017), printre alții, au reconsiderat rolul limbajului și al culturii(lor), pe de o parte, și al interacțiunii sociale și practicilor publice, pe de altă parte, ca fiind în mod egal constitutive pentru structurile mentale și procesele cognitive. Cercetătorii care adoptă o abordare orientată spre dimensiunea comunicativă (Müller, 2010, 2017; Deignan și Cameron, 2013; Deignan, 2017; Jensen, 2017 ș. a.) acordă, la rândul lor, o atenție semnificativă dihotomiei care are în vedere aspectul stabilității sau al dinamicității metaforei.

În peisajul curent al cercetării, există un interes crescând pentru studiul metaforei în interacțiunea și comunicarea vie în diferite contexte și situații, sau, în termenii care s-au încetățenit deja, al metaforei ,în sălbăticie”, ,,in the wild”: „Preferința mea personală este de a vedea fluturii în sălbăticie, chiar dacă acest lucru îi face mai greu de studiat în comparație cu specimenele moarte dintr-un laborator [...]. Putem, desigur, examina metaforele și „sub sticlă", ca și când ar fi plasate individual pe o coală de hârtie, pentru a înțelege mai bine structura și posibilele lor sensuri"12 (Gibbs, 2017a, p. 320).

Se presupune astfel că observarea metaforelor ,în sălbăticie”, i. e. ,în dimensiunea uzului" în diferite contexte, ar putea conduce la intuiții noi în privința unor ,aspecte ale dinamicii discursului și ale construcției întrupate a sensului"'13 (Müller, 2017, p. 297).

În general, cercetătorii sunt de acord că metafora se ivește ,în uz pentru a răspunde unor nevoi și funcții comunicative particulare și deseori specifice" "14 (Evans, 2013, p. 75). Există totuși câteva studii care își propun să pună sub semnul întrebării aşa-numita funcție comunicativă a metaforei. Probabil studiul care iese în evidență, din acest punct de vedere, este cel al

12 „My personal preference is to see butterflies in the wild, even if this makes them more difficult to study compared to dead specimens in a laboratory. [...] We can, of course, still examine metaphors «under glass» as when placed individually down on paper, to better understand their structure and possible meanings".

13 ,aspects of discourse dynamics and embodied meaning-making”.

14 ,in language use to address particular and often specific communicative needs and functions". 
lui Jensen (2017). Autorul își exprimă explicit dezacordul cu tratamentul metaforei ca un fapt de comunicare și explică acest lucru printr-o raportare la înțelegerea curentă a termenului de „,comunicare”: „comunicarea [...] presupune ideea a doi interlocutori separați care trimit ceva (gânduri, idei, sentimente, directive, metafore etc.) înainte și înapoi" ${ }^{15}$ (Jensen, 2017, p. 260). Metafora ar presupune, în acest caz, un uz instrumental al limbajului, prin intermediul căruia, sensurile metaforice, reificate sub forma unor produse ale unei minți individuale, sunt trimise spre un alt individual pentru a servi unor „,nevoi comunicative”. Jensen propune, în schimb, o trecere de la ideea metaforei ca produs folosit în comunicare, la „metafora ca proces al creației și al producerii în act a unui tip de semnificație metaforică, i. e. dublă"16 (2017, p. 259)în ,'lumea împreună cu altul' a dialogului” („'inter-world' of dialogue”). Această focalizare asupra metaforei ca ceva ce „facem” (i. e. activitate, proces) ,în construcția activă și explorativă a sensului" ${ }^{17}$ (Jensen, 2017, p. 261), în opoziție cu ceva ce ,avem deja” (i. e. produs) și cu care putem comunica, este sugerată și de abordarea dinamică a lui Gibbs (2017a, p. 320) a metaforei: „Eu vorbesc intenționat mai degrabă despre 'performarea metaforică', decât despre 'uz metaforic', deoarece aspectul de 'perfomare' acordă atenția necesară faptului că metaforele sunt produse în act și nu pur și simplu selectate pentru uz dintru tezaur mental" ${ }^{\text {"18 }}$. Totuși, în contrast cu Gibbs, Jensen pare să aibă în vedere o reconceptualizare a dimensiunii comunicative a metaforei, elaborând ideea că aceste sensuri metaforice sunt create într-o ,ecologie inter-personală” (Jensen, 2017, p. 257) și deci că metafora emerge ca realizare comună sau împărtășită în interacțiunea umană. Spre deosebire de alți autori care abordează metafora ca un proces dinamic-creativ, dar consideră această dinamicitate și creativitate a limbajului și metaforei ca fenomene care apar exclusiv în uzul lingvistic, devenind astfel o „funcție a discursului”, Jensen adoptă perspectiva inversă şi consideră creativitatea și alteritatea (sau intersubiectivitatea) ca dimensiuni esențiale care concură reciproc la ,procesul de conceptualizare metaforică”. La prima vedere, această abordare pare foarte apropiată de conceptul cardinal de creativitate (lingvistică și metaforică) al lui Coșeriu, i. e. energeia, ale cărui origini pot fi descoperite, mai întâi, în conceptualizarea din ontologia aristotelică, iar mai târziu, în îmbogățirea conceptuală a acestuia cu dimensiunea intersubiectivității din antropologia

15 ,communication [...] entails an idea of two separate interlocutors that send something (thoughts, ideas, feelings, directives, metaphors, etc.) back and forth".

16 ,metaphor as a process of creating and enacting some kind of metaphorical, i. e. double meaning".

17 ,in our active and explorative sense-making”.

18 „I purposely talk about 'metaphor performance' rather than 'metaphor use', because 'performance' gives proper attention to the fact that metaphors are enacted and not simply selected for use from a mental thesaurus". 
humboldtiană. Fără a intra în detalii, rămâne, totuși, foarte dificil de acomodat noțiunea coșeriană de energeia, „creativitate în și prin alteritate” (Borcilă, 2002) cu perspectiva lui Jensen. Cele două perspective, cea a lui Coșeriu și cea a lui Jensen, se întemeiază pe tradiții diferite de cercetare: înțelegerea lui Coșeriu a creativității dezvoltă idei care își au punctul de origine în filosofie (Aristotel, Humboldt, Heidegger, Dewey, MerleauPonty, Pagliaro), pe când Jensen își fundamentează punctul de vedere pe teoria sistemelor dinamice. Adoptând această teorie, Jensen este, în cele din urmă, forțat să vadă dimensiunea creativă și dialogică a metaforei „, ca încapsulată în dinamica supra-individuală care ia naștere din permanenta schimbare și reorganizare a sistemului (de interacțiune)"19 (Jensen, 2017, p. 262). În aceste condiții ne vedem forțați să întrebăm: ,a cui creativitate?”, „a cui alteritate?” și, de asemenea, de ce, care este motivația pentru emergența metaforei?

3.3. Perspective unificatoare. Mergând mai departe la cea de-a treia linie de cercetare, putem observa că există câteva încercări de a oferi o perspectivă unificată a studiului interdisciplinar al metaforei. Reprezentanţi ai acestor orientări unificatoare sunt, în special, R. Gibbs și M. Johnson.

Într-un interviu recent, Gibbs admite că întreaga lui activitate de cercetare ,a fost pusă în slujba indicării conexiunii dintre multe și diverse teorii ale metaforei, fără a încerca să favorizeze o anumită perspectivă în detrimentul alteia" ${ }^{20}$ (Rasulíc, 2017, p. 140-141). Decât să adopte „poziții retorice” „rezistente” la alte perspective, fapt care ar ține în viață ,războaiele metaforei” în moduri neproductive, el sugerează că cercetătorii ar trebui mai degrabă să accepte că ele sunt complementare și că interacțiunea lor ar putea spori cunoașterea noastră a fenomenului (Gibbs, 2017a, 2017b). El propune un punct de vedere în care variate niveluri ale analizei - al evoluției, istoric, socio-cultural, discursiv, lingvistic, cognitiv, psihologic, neural etc. - să fie considerate ,interactive”. Totuși, rămâne foarte neclar, în această abordare, cum pot fi relaționate între ele toate aceste niveluri, fără elaborarea prealabilă a unui cadru unitar, pe baza căruia diferitele orientări pot fi reinterpretate și integrate.

Cel de-al doilea proiect unificator ambițios este cel al lui Mark Johnson, care propune o teorie integrativă a ,semnificației și gândirii”, pe care el o numește „estetica semnificației întrupate” ${ }^{21}$. El înțelege termenul „estetică” în acord tradiţia provenită din Dewey, pentru care estetica trebuie elaborată

19

„as embedded in supra-individual dynamics arising from the constant change and reorganization of the system (of interaction)".

${ }^{20}$,research has been devoted to showing the connections between many diverse theories of metaphor and to not simply favor one view to the exclusion of all other".

${ }^{21}$ În mod curios, Johnson nu tratează metafora în abordarea sa a „semnificației și gândirii”" (Johnson, 2017, 2018). Totuși, noțiunea lui de schemă imagistică (Johnson, 1987) $\mathrm{a}$ fost fondațională pentru dezvoltarea TCM, la fel cum sunt și componentele experienței semnificative, în termeni mai recenți, pentru ,întreaga cogniție î̉ ansamblu”, incluzând aici arta, filosofia, știința și moralitatea (a se vedea, în acest sens, și titlul cărții lui Johnson: The aesthetics of meaning and thought: the bodily roots of philosophy, science, morality, and art). 
pornind de la o concepție asupra experienței (Leddy și Puolakka, 2021). La fel ca acesta din urmă, Johnson înțelege estetica ca fiind „,nu doar o explorare teoretică a naturii artei [...], ci mai curând ca aparținând tuturor proceselor prin care orice aspect al experienței noastre poate fi semnificativ"22 (Johnson, 2018, p. 24). Dacă esteticul se referă modul în care se ivește semnificaţia, componentele acestei experiențe semnificative sunt constituite de imagini, scheme imagistice, calități și emoții. Aspectul care merită o atenție deosebită în această nouă abordare este rolul pe care îl acordă Johnson dimensiunii emoțional-afective a semnificației. Modul în care autorul conceptualizează emoția pare a avea un mare potențial de a fi integrat în teoria integralistă a metaforei.

3.3.1. Metaforă și afectivitate. Înainte de a trece la prezentarea conceptului de emoție în tratarea lui Johnson, subliniem că referiri la acest concept sau chiar abordări in extenso există și în alte studii elaborate din perspectivă ,cognitivă”. Chiar dacă nu formează un câmp omogen de cercetare ele trebuie menționate.

Una dintre ideile revolutionare a TMC (Lakoff și Johnson, 1980) a fost aceea că domeniile abstracte, în care se încadrează și domeniul emoțiilor, sunt în general conceptualizate prin metafore. Fiind mai puțin accesibile imagistic și experiențial, în cazul acestor domenii este necesar un transfer al unui conținut schematic-imagistic de la un domeniu-sursă la un domeniu-țintă. Astfel, în expresii lingvistice precum Clocotea de furie sau A explodat la auzul acestor cuvinte, înțelegem furia în termenii unui fluid care fierbe sau care se află sub presiune într-un container. Conceptualizarea emoțiilor prin metaforă, care, ulterior, poate fi transpusă în alte sisteme semiotice (limbaj, gesturi etc.) a devenit chiar unul dintre domeniile predilecte de studiu în lingvistica cognitivă (vezi, de exemplu, Kövecses, 1986, 1990, 2003).

Mai recent, Deignan și Cameron (2013, p. 227) se referă la o dimensiune emotiv-afectivă a sensurilor metaforice și menționează că „o mare parte a sensurilor metaforice par să se ivească în expresii semi-fixate, cu forme relativ stabile sintactic și lexical și sensuri specific afective și pragmatice, ${ }^{, 23}$. Tratarea expresivității limbajului și, în particular, a dimensiunii lui expresive ca parte a interacțiunii vii între vorbitori, pare a fi o practică curentă în cazul multor direcții din lingvistica actuală. În această înțelegere, afectivitatea este conceptualizată ca ofuncție a discursului: ea este rezultatul uzului limbajului, în sensul în care limbajul însuşi este pus în serviciul, i. e. este folosit instrumental, pentru exprimarea emoției și afectivității cuiva.

Din perspectiva orientării care își propune să explice dinamicitatea metaforei în uz, Müller (2017) abordează problema afectivității dintr-un unghi diferit de cel al cercetătorilor menționați anterior. Pentru ea, construcția

22 ,not just as theoretical exploration of the nature of art [...], but rather as pertaining to all the processes by which any aspect of our experience can be meaningful".

${ }^{23},[\mathrm{~m}] \mathrm{uch}$ metaphorical meaning seems to occur in semi-fixed expressions, with relatively stable syntactic and lexical patterns and specific affective and pragmatic meanings". 
sensului metaforic se face pornind de la „un proces în care vedem și simțim un domeniu experiențial în termenii altui domeniu" ${ }^{24}$ (Müller, 2017, p. 300). Important în această tratare este faptul că autoarea precizează că în acest proces de înțelegere a domeniului-țintă în termenii domeniului-sursă, afectivitatea intervine în chiar, ,selectarea” ",calităților experiențiale ale domeniului sursă",25. Din păcate, autoarea nu dezvoltă teoretic această intuiţie semnificativă pentru cercetarea metaforei, intuiție care credem că ar fi meritat o atenție deosebită.

O sinteză cuprinzătoare a eforturilor de a aborda acest fenomen prezintă Foolen (2012). Autorul discută patru perspective din care a fost luată în considerare „relevanța” conceptului de „emoție” pentru limbaj și lingvistică și posibilele ,relații” care pot apărea între emoție și limbaj. O primă perspectivă are în vedere relația dintre conceptualizare și limbaj, pe de o parte, și a celor două în raport cu emoția. Dacă se pornește de la asumpția bazică a TMC, potrivit căreia metafora este în mod fundamental un fapt care aparține gândirii, și nu limbajului, atunci emoția este un sentiment care poate fi conceptualizat $l a$ nivelul gândirii , iar această gândire poate fi, ulterior, „reflectată ” $\hat{\imath}$ limbaj ${ }^{26}$ (Foolen, 2012, p. 349). Din acest punct de vedere, noi avem ,abilitatea” de a conceptualiza emoții pe care le putem exprima, în limbaj, prin diferite părți de vorbire: substantive (dragoste, ură, surprizăa, fricăa, regret, entuziasm, nemulțmire ș. a.), verbe (a urî, a adora, a iubi, a surprinde, a pizmui, a jindui, a se teme ș. a.), adjective (supărat,-ă; fericit,-ă; nervos,-oasăa), adverbe (mizerabil, înfricoşător, speriat) etc. O a doua perspectivă vizează relația directă între emoție și limbaj: emoția poate fi exprimată direct în vorbire, fără a mai trece, deci, printr-o dimensiune conceptuală. Această conexiune nemediată între emoție și limbaj poate fi observată atunci când cineva reacționează afectiv, într-un mod direct, printr-o interjecție de tipul Ura!, la bucuria pe care o transmite altcineva printr-un enunt de tipul: $A m$ intrat la facultate! Autorul ilustrează, printr-o serie de exemple, ideea că, în mod direct, emoțiile pot fi exprimate în limbaj prin prozodie, morfologie, sintaxă și construcții cu sens figurativ sau metaforic. A treia perspectivă în considerarea relației dintre limbaj și emoție vizează „posibilele variații” ale acestei relații, în funcție de tipul de emoție. Autorul susține că o emoție care se bazează pe o anumită credință este mai susceptibilă de a fi exprimată în limbaj, în comparație cu alte emoții, precum frica și spaima care pot fi „doar conceptualizate în limbaj, dar exprimate în moduri non-verbale"27 (Foolen,

${ }^{24}$,a process of seeing and feeling one experiential domain in terms of another”.

25 ",[This involves presenting selected] experiential qualities of the source domain. [it involves feeling und understanding]".

${ }^{26}$ În acest caz, după cum remarcă și Foolen (2012, p. 349), „,nu există nici o conexiune directă între emoție și limbaj” (,,[t]here is no direct connection between language and emotion"), deoarece, în această perspectivă, limbajul nu ar avea nicio funcție cognitivă: el este doar o „reflectare” sau „specializare” a unor ,,abilităţi cognitive generale” (Barcelona, 2002, p. 2).

„only conceptualized in language, but expressed in non-verbal ways”. 
2012, p. 350), prin intermediul unor sisteme semiotice, precum gestica, mimica etc. A patra perspectivă abordează relația dintre emoție și limbaj astfel: „limbajul reflectă conceptualizarea emoției și exprimă emoția”, având, în consecință, ,o legătură atât directă, cât și indirectă cu emoția”. ${ }^{28}$ În acest moment se pune și problema afectivității ca fiind „fondațională”, i. e. „primară și necesară” pentru întreaga cogniție și, în consecință, și pentru achiziția limbajului, atât din punct de vedere filogenetic, cât și ontogenetic.

Abordarea pe care o propune Johnson asupra fenomenului $(2017,2018)$ ar putea fi încadrată în această a patra perspectivă despre care vorbește Foolen (2012). Menționăm, în acest context, că la Johnson găsim și o tratare extensivă din punct de vedere teoretic a dimensiunii emoționale a semnificației. Pe de altă parte, în raport cu alte puncte de vedere, viziunea lui este în mod esențial bazată pe o tradiție diferită de cercetare, preluând idei care își au originea în opera lui William James, John Dewey și Antonio Damasio. Johnson (2017, p. 32) pornește de la observația că atât „filosofia tradițională a limbajului”, cât și știința limbajului ,au tins fie să minimizeze, fie să respingă în întregime dimensiunea emoțională a semnificației. C. K. Odgen și I.A. Richards (1923) au netezit calea în această direcție când au distins sensurile 'descriptive' de cele 'emotive' și când au concluzionat că doar primele au conținut cognitiv semnificativ relevant pentru cunoașterea și înțelegerea lumii noastre. Rezultatul nefericit al acestei bifurcații nelegitime a gândirii și afectivității, rațiunii și emoției, a fost până chiar de curând, ignorarea emotiiilor în abordarea limbajului de către curentele principale de gândire"29. Potrivit lui Johnson, mai ales odată cu „marea” descoperire a lui Damasio, potrivit căreia emoția joacă un rol central în gândirea și semnificarea umană, întreaga tradiție bazată pe dualismul cartezian și pe respingerea emoției a căzut în dizgrație. Alături de viziunea lui Damasio, o intuiție pe care Johnson o exploatează este cea a lui W. James asupra „gândului-emoție” (,thought-feeling”): „fiecare gând are o dimensiune afectivă ce include atât un sens simțit al orizontului [...] sensului care înconjoară un anumit termen, cât și intuiția direcției gândirii noastre"30 (Johnson, 2017, p. 32). Mai decisivă este însă influența lui Dewey asupra conceptului de emoție elaborat de Johnson. La fel ca Dewey, Johnson consideră emoția drept o calitate care ,infuzează” întreaga experiență și

28 „language reflects conceptualization of emotion and expresses emotion”, „has both a direct and an indirect link to emotion".

29 ,have tended to either downplay or entirely dismiss the emotional dimension of meaning. C. K. Ogden and I. A Richards (1923) set the stage for this when they distinguished 'descriptive' from 'emotive' meaning, and then concluded that only the former has significant cognitive content relevant to understanding and knowing our world. The unfortunate result of this illegitimate bifurcation of thought and feeling, reason and emotion, has been, until quite recently, the ignoring of emotions in mainstream accounts of language".

30, ,all thought has a feeling dimension that includes both a felt sense of the horizon or fringe of meaning surrounding a particular term, and also a feeling of the direction of our thinking". 
constituie, în același timp, „fundament și dimensiune a cunoașterii” (Hohr, $2013)^{31}$. In organizarea conținutului cognitiv, emoția „este o calitate care ghidează selecția materialului” (Kaminsky, 1957, p. 320) și care tinde spre expresie, sortând ceea ce este relevant pentru o anume experiență și lăsând la o parte ceea ce este irelevant. Emoție și cogniție se presupun, așadar, reciproc: „emoția este forța care mișcă și care cimentează... iar prin aceasta dă unitate calitativă materialului extern disparat și eterogen"32 (Dewey, 1958, p. 42). Ea ia naștere în experiență și este despre o experiență, chiar dacă presupune, totuși, și o legătură organică cu subiectul acelei experiențe.

Luând aceste idei ca punct de pornire, Johnson argumentează că emoția și afectivitatea stau ,în centrul abilității noastre de a conceptualiza și gândi’”33 (2017, p. 33). Autorul urmărește, astfel, să explice dimensiunea fondațională a emoției pentru cunoașterea umană în întregimea ei și, în acest sens, să sublinieze faptul că emoția și afectivitatea ,impregnează” tot ceea intră în sfera semnificativităţii.

Conceptualizarea acestui fenomen de către Johnson este compatibilă cu abordarea lui Coșeriu a emotivității și afectivității ca dimensiuni intrinseci ale semnului lingvistic și metaforei. În teoria sa a metaforei, Coșeriu (2001 [1956]) discută Modelul „Organon” al lui Bühler cu cele trei funcții: expresie (indicarea sau exprimarea atitudinilor și emoțiilor vorbitorului), reprezentare (reprezentarea obiectelor și stărilor de lucruri) și apel (influențarea atitudinilor vorbitorului) (Bühler, 1990 [1934], p. 35). Coșeriu subliniază că aspectele subiective și tot ceea ce ține de domeniul emoționalului au fost în general asociate cu creativitatea. De aici până la concluzia că aspectul creativ al limbajului ar aparține „exclusiv” anumitor funcții ale uzului limbajului a fost suficient un singur pas: „există tendința de a identifica 'limba' cu funcția informativă (adică cu 'limbajul enunțiativ') și, de a considera, în consecință, creația ca fenomen care aparține exclusiv funcției expresive și apelative" (Coșeriu, 2001 [1956], p. 19). Pasul hotărâtor înspre îndepărtarea față de această perspectivă a fost făcut de Coșeriu prin elaborarea noțiunii de creativitate. În conceptul de energeia („creativitate în și prin alteritate”), aspectul creativ nu este separat de aspectul emotiv-afectiv, deoarece creativitatea se naşte din chiar nevoia de a împărătăşi $c u$ şi pentru un altul un conținut trăit și simțit afectiv. Coșeriu adoptă aici punctul de vedere al lingvisticii antropologice humboldtiene, care afirmă că toate puterile nedivizate ale umanului (emoție, intelect, sensibilitate) fuzionează și participă împreună la energeia limbajului: „Nu există nici o forță a sufletului care să nu fie angrenată în această activitate" (Humboldt, 2008 [1936], p. 119). Subiectivitatea, emoția și afectivitatea caracterizează, în consecință, activitatea de vorbire umană în întregimea ei.

31 Pentru dependența reciprocă dintre cogniție și emoție la Dewey, a se vedea Hohr (2013).

32 „Emotion is the moving and cementing force [...] thereby giving qualitative unity to materials externally disparate and dis-similar".

33 ,at the heart of our ability to conceptualize and reason”. 
În ciuda unor inerente puncte de dezacord, conceptul lui Johnson de „emoție" poate fi integrat în teoria integralistă a metaforei. Potrivit cadrului teoretic coșerian, orice integrare comprehensivă a direcţiilor actuale şi/sau a unora dintre conceptele lor cardinale în lingvistica integrală nu poate fi făcută decât printr-o reinterpretate a lor pe baza unitară a concepției proprii. Menționez, în acest context, că teoria integralistă a metaforei a profitat deja de o altă inovație propusă în cadrul „,cognitiv”, respectiv de conceptul de „schemă imagistică”. Urmând sugestiile făcute de Coșeriu (Coșeriu, 1990; 1992 [1989-1990]; 2000 [1990], § 7.1.), asumpția cognitivă potrivit căreia în procesul de „categorizare” a experienţei, conţinutului conceptual i se ,asociază” şi o ,schemă mentală”, o structură schematic-imagistică, emegentă în experienţa noastră în lume, a fost reinterpretată pentru procesul metaforic astfel: schema imagistică nu este o reprezentare abstrasă ca atare din mediul pre-verbal, în care se presupune că a emers, ci este o imagine creată spontan în procesul metaforic însuși și prin ,asociere" cu un conținut lexical (Borcilă, 2003, 2013; vezi și Faur, 2013a, 2013b).

Combinând sugestiile lui Johnson privind dimensiunea fondatioanlă a emoției pentru cunoaștere umană cu specificările privind caracterul intersubiectiv al afectivității, sintetizate în termenul de ,inter-afectivitate”, elaborat de Fuchs și Koch $(2014)^{34}$, credem că putem ajunge la o a îmbogăţire a cunoașterii asupra conținutului conceptual al „schemei afective”, propuse, în cadrul teoriei integraliste a metaforei, de Borcilă (2013). Interesant este faptul că, deși Fuch și Koch (2014) exploatează aproximativ aceleași surse teoretice pe care le are la îndemână și Johnson (operele lui A. Damasio, W. James, J. Dewey și M. Merleau-Ponty), cei doi autori se focalizează, prin contrast cu Johnson, asupra faptului că emoțiile „,sunt în mod esențial relaționale” ${ }^{\text {35 }}$ (Fuchs și Koch, 2014, p. 508), deci intersubiective. Fiind afectat de o situație experiențială, corpul unui subiect tinde spre expresie, spre exprimarea vizibilă a propriei stări interioare către un altul. Această expresie, percepută de un altul, produce, în acesta din urmă, „o impresie”, prin care trăiește el însuși o experiență similară

${ }^{34}$ Menționăm că termenul de ,inter-afectivitate” a fost preluat de Zlatev și colegii săi în cadrul „Modelului Sedimentării și Motivării” metaforei (v. Zlatev, Jacobsson și Paju, 2021; cf. și Devylder și Zlatev, 2020, Stampoulidis, Bolognesi și Zlatev, 2019). Autorii prezintă un model metaforic pe trei paliere, care a fost inspirat de cele trei niveluri ale limbajului ale lui Coșeriu, respectiv universal, istoric și individual (Coşeriu, 2007), și de fenomenologia lui Merleau-Ponty. Nu ne propunem, aici, să oferim o prezentare extensivă a acestui model, deoarece tratarea lui, și în special relaţia acestui model cu matricea coșeriană din care se inspiră, ar merita un spațiu foarte extins. Menționăm că termenul de ,inter-afectivitate” a fost preluat de Zlatev şi colegii săi în cadrul „Modelului Sedimentării și Motivării” metaforei (v. Zlatev, Jacobsson și Paju, 2021; cf. și Devylder şi Zlatev, 2020, Stampoulidis, Bolognesi și Zlatev, 2019). Autorii prezintă un model metaforic pe trei paliere, care a fost inspirat de cele trei niveluri ale limbajului ale lui Coșeriu, respectiv universal, istoric şi individual (Coșeriu, 2007), și de fenomenologia lui Merleau-Ponty. Nu ne propunem, aici, să oferim o prezentare extensivă a acestui model, deoarece tratarea lui, și în special relația acestui model cu matricea coșeriană din care se inspiră, ar merita un spațiu foarte extins.

,,are essentially relational”. 
primului subiect. Celălalt „nu doar vede emoția” primului subiectului, ci „o și simte cu corpul propriu" (Fuchs și Koch, 2014, p. 508). La rândul ei, emoția simțită de celălalt devine din nou expresie a lui și produce o impresie afectivă asupra primul subiect. Astfel, ,amândoi partenerii vor avea experiența unei sentiment specific de a fi conectați unul cu altul într-un mod care poate fi numit 'incorporare reciprocă"”36 (Fuchs și Koch, 2014, p. 508).

Pentru a vedea cum pot fi integrate conceptul de emoție și cel de interafectivitate în teoria integralistă a metaforei, să luăm, de exemplu, metafora cer amenințător (exemplul este preluat din Brandt, 2013, p. 40). Entitățile lexicale angajate în procesul metaforic sunt reprezentate de cer (termenul A) și amenințător (termenul B). Noi avem o cunoaștere anterioară asupra modului în care cerul ar putea fi: albastru, roșu-sângeriu, albastru-argintiu, înnorat, fără nori, calm, limpede, infinit, imens etc. În raport cu această cunoaștere anterioară, la un moment dat este sesizat un aspect calitativ inedit cu privire la lexemul A (cer). Această experientă afectiv-perceptuală nouă, se află în discontinuitate cu designatele posibile ale lui A (cer), neputând fi numită direct prin lexemul A (cer) și nici calificată în vreun mod prin operațiile vorbirii enunțiative sau printr-un proces de determinare directă (pentru noțiunea de „determinare”, vezi Coșeriu, 1973 [1955-1956], p. 282-323). Ca urmare a acestui fapt, apare necesitatea unei determinări trans-domeniale, prin care aspectul perceptual insolit captat în relație cu A (cer) este pus ,în perspectiva” imaginii asociate a lexemului B (amenințător). Imaginea unui forțe naturale devastatoare apare spontan în momentul în care vorbitorul are „viziunea” noii calități a cerului. Imaginea este apoi transferată din domeniul entității lexicale amenințător în domeniul entitătii lexicale cer, împreună cu o schemă afectivă declanșată de sentimentul de frică și anxietate cauzată de pericolul iminent manifestat de o forță a naturii. Schema afectivă este ghidată de emoția care ,selectează și organizează" materialul perceptual, afectivitatea intervenind, așa cum legitim a remarcat și Müller (2017, p. 300), în chiar „selectarea” „calităţilor experiențiale ale domeniului sursă", adică ale domeniului lui B (amenințător). Astfel, pentru a capta și exprima intersubiectiv „viziunea” asupra aspectului insolit perceput în relație cu cerul, vorbitorul procedează la un transfer al imaginii aparținând domeniului lui B (amenințător) în domeniul lui A (cer). Aspectul perceptual-afectiv nou, surprins în relație cu cerul, este exprimat în mod spontan atât prin imaginea unei forțe puternice și periculoase a naturii, cât și prin sentimentele de natură negativă asociate cu această imagine și cu lexemul amenințător. Metafora cer amenințător emerge printr-o determinare trans-domenială și o identificare a celor două entități lexicale, aparținând unor domenii eterogene.

La prima vedere, exemplul analizat pare a fi o ilustrare, mai curând, a primei relații dintre emoție și limbaj, distinsă de Foolen (2014), în care nu ar exista „o conexiune directă” între cele două, ci doar una ,indirectă”,

36 „both partners will experience a specific feeling of being connected with the other in a way that may be termed 'mutual incorporation"”. 
în sensul în care lexemul amenințător reflectă doar capacitatea noastră de a conceptualiza emoții, conceptualizare care se poate reflecta, ulterior, și în limbaj. Nu credem că o astfel de judecată este însă corectă. Din punctul de vedere al teoriei integraliste a metaforei, acest exemplu ar ilustra, la limită, cea de-a patra relație identificată de Foolen (2012,p. 350), potrivit căreia „limbajul reflectă conceptualizarea emoției și exprimă emoția”. Indiferent dacă e vorba de conceptualizarea unor emoții în limbaj (cum ar părea să ilustreze metafora analizată) sau de metafore care nu vizează deloc domeniul emoțiilor (precum: Acest avocat este un rechin, cenuşa ochilor ș. a.), afectivitatea este prezentă chiar în acest sens esențial elaborat de Johnson, ca fondațională pentru cunoaștere și limbaj (inclusiv cel metaforic).

Această abordare contrastează, totuși, cu rolul pe care orientarea „cognitivă” îl atribuie schemelor imagistice și „emoției”. Spre deosebire de cadrul de lucru ,cognitiv”, unde aceste noțiuni sunt fenomene pur psihologice și pre-verbale, în cadrul integralist ele sunt reinterpretate ca fenomene semantice, deoarece emerg în actul designației. Conceptele lui Johnson de „imagine”, „schemă imagistică”, „emoție”, ,afectivitate” sunt concepute ca entități pre-existente în relație cu activitatea de vorbire: ele sunt stocate în spațiile pre-lingvistice ale unui inconștient cognitiv, iar de aici ele pot deveni active în momentul conceptualizării unor „noi realități”. Dacă Johnson concepe emoția sub forma unor calități simțite care sunt asociate structurilor pre-lingvistice ale experienței, i. e. schemele imagistice, în teoria integralistă a metaforei ele nu pot rămâne calități simțite, capabile de a fi recrutate dintrun domeniu pre-verbal, ci trebuie înțelese ca emergând în procesul metaforic însuși, prin ,asociere” cu semnificat lexical.

\section{Concluzii}

Până în prezent, teoria integralistă a metaforei a exploatat cu succes câteva dintre inovațiile introduse de TMC (Lakoff and Johnson, 2003 [1980]; Lakoff, 1987; Johnson, 1987), subliniind că aportul acesteia se încadrează la descrierea mecanismului designării metaforice (cf. Borcilă, 2003, 2013; Faur, 2013a, 2013b). Considerăm că dialogul dintre reprezentanții orientării integraliste - dezvoltate pe baza lingvisticii integrale coșeriene - și reprezentanții altor tradiții de cercetare ar trebui să continue și că este datoria noastră să ducem mai departe munca pe care Coșeriu însuși a început-o cândva pe la mijlocul secolului al XX-lea. De asemenea, este momentul ca orientările alternative - diferitele linii de cercetare din știința cognitivă actuală - să țină seama de realizările lingvisticii coșeriene și să integreze, în cadrul de lucru propriu, unele dintre soluțiile acesteia: interacțiunea dintre tradiții distincte de cercetare ar putea ajuta la rezolvarea multor probleme controversate din cercetarea actuală a metaforei și ar putea contribui, astfel, la o perspectivă îmbogățită în înțelegerea metaforei ca o resursă fundamentală a creativității umane. 


\section{Referințe bibliografice:}

1. BARCELONA, Antonio. Metaphor and Metonymy at the Crossroads: A Cognitive Perspective. Berlin: Mouton de Gruyter, 2002.

2. BOJOGA, Eugenia, Oana BOC și Cornel VÎLCU. Introduction. În: Eugenia Bojoga, Oana Boc, Cornel Vîlcu (eds.), Coseriu: Perspectives contemporaines. Tome 1. Cluj-Napoca: Presa Universitară Clujeană, p. 5-7.

3. BORCILĂ, Mircea. Lingvistica integrală şi fundamentele metaforologiei. În: Dacoromania. Serie nouă, VII-VII (2002-2003), 2003, p. 47-77.

4. BORCILĂ, Mircea. Paradigme contemporane în cercetarea lingvistică. Prelegeri doctorale, Universitatea "Babeş-Bolyai", 2013.

5. BRANDT, Line. Metaphor and the communicative mind. În: Riccardo Fusaroli and Simone Morgagni (eds.), Cognitive Semiotics: Conceptual Metaphor Theory: thirty years after. Berlin: Mouton de Gruyter, 2013, p. 37-72.

6. BÜHLER, Karl. The theory of language: the representational function of language. Translated by Donald Fraser Goodwin. Amsterdam \& Philadelphia: John Benjamin, 1990 [1934].

7. CABALLERO, Rosario and Iraide IBARRETXE-ANTUÑANO. Ways of perceiving, moving and thinking: re-vindicating culture in Conceptual Metaphor Research. In: Riccardo Fusaroli and Simone Morgagni (eds.), Cognitive Semiotics: Conceptual Metaphor Theory: Thirty Years After. Berlin: Mouton de Gruyter, 2013, p. $268-290$.

8. COȘERIU, Eugeniu. Creația metaforică în limbaj. Traducere din spaniolă de Eugenia Bojoga. În: Dacoromania. Serie nouă, V-IV (2000-2001), 2001[1956], p. 11-34.

9. COSERIU, Eugenio. Determinación y entorno. În: Eugenio Coseriu, Teoría del lenguaje y lingüística general. Cinco estudios. Madrid: Editorial Gredos, 1973 [1955], p. 282-323.

10. COSERIU, Eugenio. Structural semantics and 'cognitive' semantics. În: Logos and Language, 2000 [1990], 1:1, p. 19-42.

11. COSERIU, Eugenio. Strukturelle und kognitive Semantik. Vorlesung Wintersemester 1989-1990, Nachschrift von Ulrike Maier und Heinrich Weber. Unpublished manuscript. University of Tübingen, 1992.

12. COSERIU, Eugenio. Von den universali fantastici. În: Jürgen Trabant (ed.), Vico und die Zeichen - Vico e $i$ segni. Tübingen: Narr, 1995, p. 73-80.

13. COSERIU, Eugenio. Sprachkompetenz. Grundzüge der Theorie des Sprechens. Tübingen: Narr, ed. a II-a, 2007.

14. COSERIU, Eugenio. Geschichte der Sprachphilosophie. (Vol. 1: Von Heraklit bis Rousseau. Vol. 2: Von Herder bis Humboldt. Edited by J. Albrecht). Tübingen: Narr \& Francke, Attempto, 2015.

15. DEIGNAN, Alice. Mappings and narratives in figurative communication. În: Beate Hampe (ed.). Metaphor: embodied cognition and discourse. Cambridge: Cambridge University Press, 2017, p. 200-219.

16. DEIGNAN, Alice și Lynne CAMERON. A re-examination of UNDERSTANDING IS SEEING. În: Riccardo Fusaroli and Simone Morgagni (eds.), Cognitive Semiotics: Conceptual Metaphor Theory: Thirty Years After. Berlin: Mouton de Gruyter, 2013, p. 220-243.

17. DEVYLDER, Simon și Jordan ZLATEV. Cutting and breaking metaphors of the self and the Motivation \& Sedimentation Model. In: Annalisa Baicchi (ed.), 
Figurative meaning construction in thought and language. Amsterdam \& Philadelphia: Johns Benjamins, 2020, p. 253-281.

18. DEWEY, John. Ars as Experience. New York: Capricorn Books, 1958.

19. EVANS, Vyvyan. Metaphor, lexical concepts, and figurative meaning construction. În: Riccardo Fusaroli and Simone Morgagni (eds.), Cognitive Semiotics. Conceptual Metaphor Theory: Thirty Years After. Berlin: Mouton de Gruyter, 2013, p. 73-107.

20. FAUR, Elena. Integral Semantics and Conceptual Metaphor: Rethinking Conceptual Metaphor within an Integral Semantics Framework. În: Riccardo Fusaroli and Simone Morgagni (eds.), Cognitive Semiotics. Conceptual Metaphor Theory: Thirty Years After. Berlin: Mouton de Gruyter, 2013a, p. 108-139.

21. FAUR, Elena. Semantica cognitivă și emergența studiilor elocuționale. Teză de doctorat, Universitatea Babeș-Bolyai, 2013b.

22. FOOLEN, Ad. The relevance of emotion for language and linguistics. In: Ad Foolen and Jordan Zlatev (eds.), Moving ourselves, moving others: Motion and emotion in intersubjectivity, consciousness and language. Amsterdam: Benjamins, 2012, p. 349-369.

23. FORCEVILLE, Charles. From Image Schema to metaphor in discourse: the FORCE schemas in animation films. În: Beate Hampe (ed.), Metaphor: embodied cognition and discourse. Cambridge: Cambridge University Press, 2017, p. 239-257.

24. FUCHS, Thomas și Sabine C. KOCH. Embodied affectivity: on moving and being moved. În: Frontiers in psychology, 2014, nr. 5, 508. [online] Disponibil https:// www.frontiersin.org/articles/10.3389/fpsyg.2014.00508/full [citat 30. 09. 2021].

25. GIBBS, Raymond W. The embodied and discourse views of metaphor: why these are not so different and how can they be brought closer together. In: Beate Hampe (ed.), Metaphor: embodied cognition and discourse. Cambridge: Cambridge University Press, 2017a, p. 319-334.

26. GIBBS, Raymond W. Metaphor wars: Conceptual Metaphors in human life. Cambridge: Cambridge University Press, 2017b.

27. GRADY, Joseph și Giorgio A. ASCOLI. Sources and targets in Primary Metaphor Theory: looking back and thinking ahead. În: Beate Hampe (ed.), Metaphor: embodied cognition and discourse. Cambridge: Cambridge University Press, 2017, p. 27-45.

28. HAMPE, Beate. Embodiment and discourse: dimensions and dynamics of contemporary metaphor theory. În: Beate Hampe (ed.), Metaphor: embodied cognition and discourse. Cambridge: Cambridge University Press, 2017, p. 3-25.

29. HOHR Hansjörg. The concept of experience by John Dewey revisited: conceiving, feeling and „enliving”. În: Studies in Philosophy and Education, 2013, 32, p. $25-38$.

30. HUMBOLDT, Wilhelm von. Despre diversitatea structurală a limbilor și influența ei asupra dezvoltării spirituale a umanității. Traducere în limba română de Eugen Munteanu. București: Humanitas, 2008 [1936].

31. KAMINSKY, Jack. Dewey's Concept of an Experience. În : Philosophy and Phenomenological Research, 1957, 17(3), p. 316-330.

32. KÖVECSES, Zoltan. Metaphor of anger, pride and love. A lexical approach to the structure of concepts. Amsterdam: Benjamins, 1986.

33. KÖVECSES, Zoltan. Emotion concept. New York: Springer Verlag, 1990.

34. KÖVECSES, Zoltan. Metaphor and emotion: Language, culture and body in human feeling. Cambridge: Cambridge University Press, 2003. 
35. JENSEN, Thomas W. Doing metaphor. An ecological perspective on metaphoricity in discourse. În: Beate Hampe (ed.), Metaphor: embodied cognition and discourse. Cambridge: Cambridge University Press, 2017, p. 239- 257.

36. JOHNSON, Mark. The body in the mind. The bodily basis of meaning, imagination and reason. Chicago \& London: The University of Chicago Press, 1987.

37. JOHNSON, Mark. Embodied mind, meaning, and reason. How our bodies give rise to understanding. Chicago \& London: The University of Chicago Press, 2017.

38. JOHNSON, Mark. The aesthetics of meaning and thought. The bodily roots of philosophy, science, morality, and art. Chicago \& London: The University of Chicago Press, 2018.

39. LAKOFF, George şi Mark JOHNSON. Metaphors we live by. Chicago and London: The University of Chicago Press, 2003 [1980].

40. LAKOFF, George. Women, fire and dangerous things. What categories reveal about the mind. Chicago and London: The University of Chicago Press, 1987.

41. LEDDY, Tom și Kalle PUOLAKKA. Dewey's Aesthetics. În: Edward N. Zalta (ed.), The Stanford Encyclopedia of Philosophy (Fall 2021 Edition), 2021. [online] Disponibil: https://plato.stanford.edu/archives/fall2021/entries/dewey-aesthetics/ [citat 30.09.2021].

42. LEEZENBERG, Michiel. From Cognitive Linguistics to social sciences: thirty years after Metaphor we live by. În: Riccardo Fusaroli and Simone Morgagni (eds.), Cognitive Semiotics. Conceptual Metaphor Theory: Thirty Years After. Berlin: Mouton de Gruyter, 2013, p. 140-152.

43. MÜLLER, Cornelia. The dynamics of metaphor: foregrounding and activating metaphoricity in conversational interaction. În: Cognitive Semiotics, 2010, $10: 6$, p. 85-120.

44. MÜLLER, Cornelia. Walking metaphors: embodied cognition in multimodal discourse. În: Beate Hampe (ed.), Metaphor: embodied cognition and discourse. Cambridge: Cambridge University Press, 2017, p. 297-317.

45. OGDEN, Charles K. și Ivor A. RICHARDS. The meaning of meaning. London: Routledge \& Kegan Paul, 1923.

46. RASULÍC, Katarina. A metaphor biangle: Raymond W. Gibbs and Gerald Steen. În: Metaphor and the Social World, 2017, 7:1, p. 130-151.

47. SÁNCHEZ DE ZAVALA, Victor. Funcionalismo estructural y generativismo. Madrid: Alianza, 1982.

48. SHEN, Yeshayahu și Roy PORAT. Metaphorical directionality: the role of language. În: Beate Hampe (ed.), Metaphor: embodied cognition and discourse. Cambridge: Cambridge University Press, 2017, p. 62-81.

49. SONESSON, Göran. Bats out of the belfry: the nature of metaphor, with special attention to pictorial metaphors. În: Signs and Media, 2015, 11, p. 74-104.

50. SONESSON, Göran. Two models of metaphoricity and three dilemmas of metaphor research. În: Cognitive Semiotics, 2019, 12:1, p. 1-17.

51. STAMPOULIDIS, George, Maria BOLOGNESI și Jordan ZLATEV. A cognitive semiotic exploration of metaphors in Greek street art. În: Cognitive semiotics, 2019, 12:1. [online] Disponibil: https://doi.org/10.1515/cogsem-2019-2008 [citat 30.09.2021].

52. STOCKWELL, Peter. The inflexibility of invariance. În: Language and literature, 1999, 8:2, p. 125-142.

53. VILARNOVO CAAMAÑO, Antonio. Lógica y lenguaje en E. Coseriu. Madrid: Gredos, 1993. 
54. WINTER, Bodo și Teenie MATLOCK. Primary metaphors are both cultural and embodied. În: Beate Hampe (ed.), Metaphor: embodied cognition and discourse. Cambridge: Cambridge University Press, 2017, p. 99-116.

55. ZLATEV, Jordan, Göran JACOBSSON și Liina PAJU. Desiderata for metaphor theory, the 'Motivation and Sedimentation Model' and motion-emotion metaphoremes. In: Augusto Soares da Silva (ed.), Figurative Language - Intersubjectivity and Usage. Amsterdam: John Benjamins, 2021, p. 41-73. 